\title{
Curriculum and Instruction at Exemplar Inclusive STEM High Schools
}

\author{
Erin Peters-Burton ${ }^{\mathrm{a}}$, Ann House ${ }^{\mathrm{b}}$, Ed Hanc, Sharon Lynch ${ }^{\mathrm{d}}$ \\ ${ }^{a}$ George Mason University, USA; ${ }^{b} S R I$ International, USA; ${ }^{c}$ Kipp DC, USA; ${ }^{d}$ George Washington University, USA
}

\begin{abstract}
In recent years, prominent organizations have released large-scale policy reports on the state of science, technology, engineering, and mathematics (STEM) education in the United States, with particular emphasis on curricula and instructional practices. The purpose of this paper was to examine the curriculum and instruction occurring at high performing STEM-focused high schools that have no academic conditions for student admission. This study conducted a cross-case analysis across eight case studies of contextually different but well-regarded inclusive STEM high school. Common themes that emerged included different hierarchical levels of design and implementation (classroom-level, cross-cutting school level, school-wide) as well as responsive design of curriculum and instruction. Unique contextual differences are discussed as well as implications for replication of inclusive STEM school design.
\end{abstract}

Keywords: Interdisciplinary approach, instruction, curriculum reform, inclusive stem high schools, cross-case analysis

\section{Introduction}

In recent years, prominent organizations including the National Research Council (NRC, 2011, 2012), the President's Council of Advisors on Science and Technology (PCAST, 2010a), and the National Academy of Education (NAEd, 2009) have released large-scale policy reports on the state of science, technology, engineering, and mathematics (STEM) education in the United States. There has been a particular focus on STEM curricula and instructional practices, with a push for a broad re-examination of the American system of teaching biology, chemistry, physics and, occasionally, earth science (Banilower et al., 2013). One recent notable effort to marshal STEM reform efforts was the NRC's (2012) Framework for K-12 Science Education, which laid the foundation for states to develop new K-12 science standards, called the Next Generation Science Standards (NGSS, 2013). These standards represent an attempt to better integrate science practices, crosscutting science concepts, and disciplinary core ideas across scientific disciplines to provide a stronger and more engaging foundation in science knowledge and skills for students.

Published data in the 2012 National Survey of Science and Mathematics Education (Banilower et al., 2013) demonstrate the need for these curricular and instructional reform efforts. Perhaps not surprisingly, these data indicated that the traditional science domains of biology, chemistry, and physics were treated as siloed disciplines in the majority of American high schools. Whereas $98 \%$ of high schools offered biology/life

\footnotetext{
${ }^{1}$ Corresponding author. George Mason University, Fairfax Campus, Thompson Hall 1401, 4400 University Dr. MS 6D2 Fairfax, VA 22030 , E-mail: epeters1@gmu.edu

Peter-Burton, E., House, A., Han, E., \& Lynch, S. (2018). Curriculum and Instruction at Exemplar Inclusive STEM High Schools. Journal of Research in STEM Education, 4(2), 193-212.
} 
science courses, $94 \%$ offered chemistry courses, and $85 \%$ offered physics courses, only $68 \%$ of high schools offered "integrated science" courses, a number that is likely significantly inflated due to the inclusion of "general science" and "physical science" courses typically taken by students who do not intend to study science formally past high school (Banilower et al., 2013, pp. 54-55; NAEd, 2009).

Additionally, direct whole-class instruction by the teacher was the most commonly reported strategy in high schools, with 95 percent of both science and mathematics teachers using such activities at least once a week (Banilower et al., 2013, pp. 76, 81). By comparison, only 18 percent of science teachers employed project-based learning activities (p. 76). What was similarly rare for high school science and mathematics students was having the opportunity to attend presentations by guest speakers focused on science/engineering or mathematics in the real-world workplace. According to the survey, 51 percent of high school science teachers and 78 percent of high school mathematics teachers reported never using such activities in their classes (pp. 77, 82).

The desire for more interdisciplinary STEM curricula and reform-based STEM instructional practices is becoming increasingly tied to a push to increase the number of STEM-focused schools at all grade levels (NRC, 2011; PCAST, 2010b). The hope is for such schools to experiment with and serve as testing grounds for innovative STEM curricula and instructional approaches, rather than merely providing more advanced STEM instruction (PCAST, 2010a). Such innovations could lead not just to increased student achievement, but also to enhanced student engagement in STEM for students from minority and high-poverty communities, leading to a broader and more equitable participation in STEM majors and careers by student groups traditionally underrepresented in those fields (PCAST 2010a, see p. 111). This particular goal of broadening participation has stimulated the development of a particular kind of STEM-focused schools, the inclusive STEM-focused high school (NRC, 2011). These schools aim to provide more rigorous STEM curricula, increased STEM instructional time, increased resources for STEM education, and more prepared STEM teachers than are frequently seen in traditional high schools.

\section{Purpose and Objectives}

The purpose of this paper was to examine the curriculum and instruction occurring at high performing STEM-focused high schools in the United States that have no academic conditions for student admission. This paper is part of a larger study called Omitted for Blinding which explored the characteristics of a set of eight exemplary inclusive STEM-focused high schools (ISHS) across the United States. The intent of the larger study was to develop rich, descriptive case studies of each ISHS, leading to an evidence base for identifying the critical components of these schools (described further in Table 1; Authors \& Colleagues, 2017). The study also included cross-case analyses to highlight the commonalities and explore the differences in these components across the ISHSs, which include curriculum and instruction (Stake, 2006; Yin, 2003). The purpose of this study was to investigate the curriculum and instruction provided at the ISHSs. We felt that the closer examination of curriculum and instructional practices at these schools could provide insight on school design and implementation features that enabled the teaching of STEM content designed for all students to graduate college STEM ready.

Specifically, this analysis concentrated on the "STEM-Focused Curriculum" and "Reform Instructional Strategies and Project-Based Learning" critical components, which were (Author \& Colleagues, 2017) defined as:

STEM-Focused Curriculum. Strong courses in all four STEM areas, or, engineering and technology are explicitly, intentionally integrated into STEM subjects and non-STEM subjects (Atkinson, Hugo, Lundgren, Shapiro \& Thomas, 2007; Colleagues \& Author, 2008; Scott, 2009).

Reform Instructional Strategies and Project-Based Learning. STEM classes emphasize instructional practices/strategies informed by research and immersing students in STEM content, processes, habits of mind and skills (Atkinson et al., 2007; Colleagues \& Author., 2008; Scott, 2009). Opportunities for project- 
based learning and student production are encouraged, during and beyond the school day. Students are productive and active in STEM learning, as measured by performance-based assessment practices that have an authentic fit with STEM disciplines (Atkinson et al., 2007; Colleagues \& Author 2008; NRC, 2004, 2005, 2010; Subotnik, Tai, Rickoff, \& Almarode., 2010; Scott, 2009).

The analysis examines what is taught in these schools: the range of STEM offerings, the rigors of those offerings, and the extent to which STEM permeates the school mission, informal activities, and nonSTEM subjects. Furthermore, this paper describes how STEM is taught in the ISHSs: the range of instructional practices seen in these schools and the learning opportunities fostered through those strategies.

Ultimately, the aim is to unpack the curriculum and instructional practices crucial to the design and implementation of well-established inclusive STEM schools in order to provide insights that can be valuable for STEM education and pedagogy in schools across the country.

In light of these objectives, the research questions addressed by this paper are:

1. What characteristics of STEM curriculum and instructional practices are common across eight ISHSs?

2. What distinguishing features or unique contextual characteristics of STEM curriculum and instructional practices exist across these schools?

3. What are the various contextual affordances and constraints that influence the design and implementation of STEM curriculum and instructional practices across these schools?

\section{Theoretical Framework}

The theoretical framework for the study draws on the concept of opportunity structures first used by Kenneth Roberts (1968) in studies of the conditions that might lead an adolescent towards criminal activity rather than a pathway to a productive career if certain positive avenues of development, such as educational opportunities, were blocked. Education is an important opportunity structure (Eisenhart et al., 2015). In the 21 st century, STEM education is especially salient. This study adapts the idea of education as an opportunity structure and considers the full range of deliberate or inherent supports and guidance that ISHSs may employ to help students from groups underrepresented in STEM to move into STEM college majors, jobs, and careers. With this theoretical framework as the foundation for the study, the research team conducted studies of successful ISHSs to compile a set of candidate critical components that may work in conjunction to provide a strong STEM education to students. The 14 critical components (Table 1) represent working hypotheses for the basis of a theory of action for ISHSs, supported by the existing body of research on inclusive and selective STEM-focused high schools (Author \& Colleagues, 2014; Author \& Colleagues, 2017).

Table 1.

Critical Components for Inclusive STEM High Schools

STEM-Focused Curriculum

Reform Instructional Strategies and Project-Based Learning

Integrated, Innovative Technology Use

Blended Formal/Informal Learning Beyond the Typical School Day, Week, or Year

Real-World STEM Partnerships

Early College-Level Coursework

Well-Prepared STEM Teaching Staff

Inclusive STEM Mission

Administrative Structure

Supports for Underrepresented Students 
Dynamic Assessment Systems for Continuous Improvement

Innovative and Responsive Leadership

Positive School Community and High Expectations for All

Agency and Choice

*See Lynch et al., 2017 for detailed description of components not related to this paper.

Among the fourteen critical components, this paper focuses on the first two listed, (a) STEM-focused curriculum and (b) the use of reform instructional strategies and project-based learning. While the remaining components are seen as critical to effective inclusive STEM schools, the components of curriculum and instruction affect the core of the educational experience (Elmore, 1996; Mehta \& Cohen, 2017). Curriculum is critical since it is the foundation of classroom instruction, and coherent curricula and standards are key indicators of successful K-12 STEM schools (Atkinson et al., 2007; Colleagues \& Author, 2008; NRC, 2011; Scott, 2009; Subotnik et al., 2010). Instruction is also a focus of this analysis, since effective STEM instruction is important because the ways students access and engage with content is as influential in student learning as the content itself (NRC, 2011).

Conceptualization and implementation of effective STEM education requires more than merely the emphasis on more science and mathematics courses (Lamberg \& Trzynadlowski, 2015). Rather, the integration of STEM should promote interdisciplinary lessons which help to support interconnections not only among the STEM subject matter (Eleftheria, Sotiriou, \& Doran, 2016), but also connects in-school learning to real-world situations (Breiner, Harkness, Johnson \& Koehler, 2012; Johnson, 2013; Rennie, Venville, \& Wallace, 2012; Roehrig, Moore, Wang \& Park, 2012). Integrated STEM education has been shown to increase high school students' learning in physics and pursuit of postsecondary STEM education (Fang, 2013). Even elementary students who experience rigorous and integrated STEM instruction had improved content knowledge and process skills (Cotabish, Dailey, Robinson, \& Hughes, 2013).

In addition to integrated content, STEM education has been found to have positive impacts when it is connected to real-world STEM practices. The National Research Council (NRC, 2011) and the President's Council of Advisors on Science and Technology (PCAST, 2010a) both emphasize that effective STEM instruction aims to foster a deeper engagement with the sciences and mathematics domains by providing personal and team-oriented opportunities for students to be involved in real-world STEM practices. In addition, explicitly providing real-world connections for students in curriculum and instruction have demonstrated increases in interest, outcome expectations, goal setting, and content knowledge (Grubbs \& Deck, 2015; Hiller \& Kitsantas, 2014).

Real-world connections make instruction more authentic and meaningful to students. Instruction that is set in an authentic context also promotes 21 st Century skills, such as creativity, communication, collaboration and critical thinking. Student-centered teaching techniques that involve student collaboration and communication have been shown to be key to student motivation, persistence, and positive social interactions (Lamb, Akmal, \& Petrie, 2015; Morrison, Roth-McDuffie \& French, 2015). In addition, Twenty-first Century skills are not only important to pursuing STEM careers (Lent, Brown, \& Hackett, 1994; Mohr-Schroeder et al., 2014), but are important skills that are used in daily life (Carroll, 2015). van Breukelen, Smeets and de Vries (2015) found that explicit teaching and scaffolding during authentic design challenges strengthened both content knowledge and skill performance.

The National Research Council (NRC, 2011) and the President's Council of Advisors on Science and Technology (PCAST, 2010a) have also both emphasized that effective STEM instruction aims to engage students within and beyond the classroom to include partnerships with STEM professionals. Community partnerships are one way to extend STEM instruction beyond the classroom, and interaction with STEM professionals through school activities have instilled a high degree of autonomy and sense of responsibility 
in students (Watters \& Diezmann, 2013). Participation in out of school STEM learning have had a positive impact on in-school science and mathematics scores (Chung, Cartwright \& Cole, 2014), STEM career interest (Reynolds, Yazdani, \& Mazur, 2013), and choice of STEM major (Sahin, 2013). Students from groups typically underrepresented in STEM benefit from authentic experiences that blend in school and out of school STEM instruction in areas such as increasing positive attitudes toward STEM (Naizer, 2014), pursuit of STEM careers (Denson, Austin, Hailey, \& Hauseholder, 2015; Rahm \& Moore, 2015), and environmental engagement (Oyana et al., 2015). This paper explores the extent and variety of ways that STEM curriculum and instruction are present in eight case study ISHSs.

\section{Methods}

Before cross-case analyses were conducted, individual case studies of the schools were composed (Stake, 2006). In this section, we first describe an abbreviated version of the methods for the larger individual case studies to explain the actions taken to reduce threats to validity for the source material. The full description of the methodology can be found at Author and Colleagues (2018). We then describe the methods for the curriculum and instruction cross-case analysis.

\section{Individual Case Studies}

Schools in this study needed to meet three criteria: (a) identify as a STEM-focused school, (b) have open admissions that were not dependent on prior academic performance, and (c) serve students in grades 9-12. The schools could use a random chance lottery if they had more interested students than available seats. A panel of experts in STEM education recommended 35 schools to the research team. Of these 35 schools, 18 were eliminated because they were not STEM focused or did not allow open enrollment. Six of the schools were eliminated because they were new and did not yet serve 9-12 grades. Eight of the schools from the remaining 11 were selected for their geographic diversity and wide variety of educational models. Table 2 lists the eight case study schools, their location, and a brief description of each school. We have obtained permission to use the school's actual names.

Table 2.

Description of eight case study schools

\begin{tabular}{lll}
\hline School & Location & Brief Description \\
\hline $\begin{array}{l}\text { Chicago High School for Agricul- } \\
\text { tural Sciences (CHSAS) }\end{array}$ & Chicago, IL & $\begin{array}{l}\text { Established in 1985, CHSAS is a public magnet } \\
\text { high school providing career-technical education in } \\
\text { agriculture. }\end{array}$ \\
& &
\end{tabular}

Denver School of Science and Denver, CO

Technology: Stapleton High School (DSST)

Dozier-Libbey Medical High School Antioch, CA (DLMHS)

Gary and Jeri-Ann Jacobs High Tech High School (HTH)
San Diego, CA
Focused on intensive college preparation, DSST was the first school in the public charter DSST STEM network.

Opened in 2008, DLMHS is a public school located in Antioch, California, and has a focus on health and medicine.

Part of a network of public charter schools, HTH engages students in project-based learning and internship experiences. 
Manor New Tech High School

(Manor)

The Metro Early College High

School (Metro)

Metro Urban Science Academy

(USA)

Boston, MA

Goldsboro, NC

Columbus, $\mathrm{OH}$
Located near Austin, Manor is a district high school and a member of the New Tech Network of schools using project-based learning.

Metro is a semi-public, non-charter, privately funded high school located on the campus of The Ohio State University and offers students the opportunity to take Ohio State University courses.

USA is a science-focused Boston public high school, which is accessible to all students living in the city. The school was originally part of an initiative to have smaller schools in urban areas.

Wayne is a public high school opened in 2007,

providing a focus on STEM disciplines.

(Wayne)

${ }^{*}$ See Lynch et al., 2017 for detailed description of participating school contexts and related student outcomes.

Before each site visit, the research team conducted a document analysis of materials found on the internet such as admission applications, mission statements, and recruitment materials of each of the eight selected schools as well as interviewing a school-based coordinator about the critical components found at the school. The visits to the ISHSs consisted of a four-day schedule for six researchers, who formed three teams of researcher pairs. A sample schedule with all the events of an ISHS visit can be found in Table 3.

Table 3.

Data Collection Activities at Site Visit to Manor New Tech High School (Lynch et al., 2017)

Classroom observations

- $\quad$ STEM Classes (Phylgebrics, Biology, Geometry, Chemistry, Engineering, Pre-Calculus/Science Research and Development)

- $\quad$ Non-STEM Classes (Spanish II A, ELA Humanities, English/Economics, English 3/American History)

\section{Focus Groups}

- Teachers (Teachers of Engineering, Mathematics, Science, Technology, afterschool clubs)

- Students $\left(12^{\text {th }}\right.$ Graders on Informal learning, $11^{\text {th }}$ Graders on Science and Math, $10^{\text {th }}$ Graders on Technology and Engineering, $9^{\text {th }}$ graders on the school overall)

- Parents

Interviews

- School Personnel (School District, Dean of Students, Principal, Teacher Mentor/Coach)

- Non-School Personnel (Business Partners, UTeach Representative, Student Alumni)

\section{Other Activities}

- School Tour

- School-wide circle time

- Teacher-led lesson development discussion

- Afterschool Key Club

- Afterschool Robotics club

- Student Astronomy Presentations Panel 
Coding. The data collection activities before and during the site visit resulted in hundreds of pages of observation notes, near verbatim focus groups and interview notes, and school-related artifacts. Two researchers coded independently and discussed the codes until there was consensus with all coding for the documents. Coding of the documents was both deductive, using the critical component definitions as a code book (the first 10 components listed in Table 1), and inductive, coding for any emerging themes that were deemed meaningful to the study (which emerged as the last four components listed in Table 1). The final case study report was reviewed and edited by the full site visit team, and reviewed by the school.

\section{Cross-Case Analysis}

The eight case studies, which were rich, informative descriptions of the school critical components ranging from 61 to 102 single-spaced pages each, were used for a Type 1 (Stake, 2006) cross-case analysis for this study. The text was open coded for any meaningful statements with no codebook used for this process. The codes were then compiled into a conjecture matrix with notations. Originally there were 35 codes in the conjecture matrix, and codes that were similar were collapsed into 23 broader codes that represented the major codes as seen in Table 4. The categories were subsumed into four overarching themes: (a) classroom implementation, (b) school-level learning opportunities, (c) school-wide design, and (d) responsive design.

Table 4.

Codes, categories and themes for curriculum and instruction components

\begin{tabular}{|c|c|c|}
\hline Theme & Category & Code \\
\hline \multirow[t]{2}{*}{$\begin{array}{l}\text { Classroom Implementa- } \\
\text { tion }\end{array}$} & $\begin{array}{l}\text { School focuses on students' } \\
\text { learning the content to the } \\
\text { level of mastery }\end{array}$ & 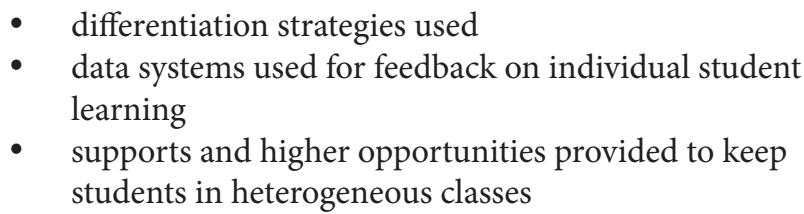 \\
\hline & $\begin{array}{l}\text { School extensively uses } \\
\text { non-traditional curricular } \\
\text { content sources }\end{array}$ & $\begin{array}{l}\text { - } \quad \text { teacher generated projects } \\
\text { - } \quad \text { community college courses } \\
\text { - } \quad \text { Project Lead the Way } \\
\text { - } \quad \text { building curriculum from various media (e.g., Kahn } \\
\text { academy) } \\
\text { - } \quad \text { rarely use textbooks }\end{array}$ \\
\hline
\end{tabular}

Cross-cutting School Lev- Collaborative group projects el Learning Opportunities are required in a variety of formats \& foci

Students participate in summative or culminating experiences

School frequently uses interdisciplinary courses and/or projects

School-wide Design
Curriculum and schedule are designed to provide academic rigor
- classroom activities

- $\quad$ projects required outside of class

- $\quad$ integrated project/problem based learning

- Advisory projects

- gateway projects

- capstone experiences

- cohesive and reflective experiences

- $\quad$ range of combinations (cross grade, cross class, whole school)

- $\quad$ range of frequency (wall to wall, several in a year)

- mathematics less involved

- grad requirements more rigorous than state requirements

- $\quad$ school offers college prep courses (including pre-calculus)

- school schedule allows for more credit accumulation

- $\quad$ students have access to virtual and college classes 


\begin{tabular}{|c|c|c|}
\hline & $\begin{array}{l}\text { Nearly all students take high } \\
\text { rigor courses }\end{array}$ & $\begin{array}{l}\text { - } \quad \text { schools offer few electives } \\
\text { most students take college prep courses (including } \\
\text { pre-calculus) } \\
\text { students take courses as a grade cohort }\end{array}$ \\
\hline & $\begin{array}{l}\text { Schools offer engineering / } \\
\text { design thinking }\end{array}$ & - offered through courses and/or a whole school theme \\
\hline & $\begin{array}{l}\text { Emphasis on real world con- } \\
\text { nections \& } 21 \text { st century skill } \\
\text { building }\end{array}$ & $\begin{array}{ll}\text { - } & \text { collaboration } \\
\text { - } & \text { problem solving } \\
\text { - } & \text { self-directed learning }\end{array}$ \\
\hline & Strong teacher collaboration & $\begin{array}{ll}\text { - } & \text { shared course or project design } \\
\text { - } & \text { shared student assessment } \\
\text { engagement in school planning \& design }\end{array}$ \\
\hline Responsive Design & $\begin{array}{l}\text { Schools use data-driven } \\
\text { decision making to improve } \\
\text { instruction }\end{array}$ & $\begin{array}{l}\text { - used at classroom level } \\
\text { - used at whole school level }\end{array}$ \\
\hline & $\begin{array}{l}\text { Schools are challenged with } \\
\text { the entry level skills of in- } \\
\text { coming 9th graders }\end{array}$ & - typically lower in mathematics \\
\hline
\end{tabular}

The team then examined the data and rated the prominence and utility of each of the 12 categories at each school. The ratings were made on a four-point rubric. For prominence, a 0 indicated no evidence for the category at the school; 1, the category was observed but not prominent; 2 , the category was present, obvious, and an inherent aspect of the school operation; and 3, the category was a major design feature of the school. For utility, a 0 indicated no use of the category at the school; 1 , the category was used in minor ways; 2 , the category was used in frequently but not widely or widely but not frequently; and 3, the category was used frequently and widely across the school.

Guided by the ratings of utility and prominence, the 12 categories were developed narratively in the paragraphs of the cross-case analysis. The narrative was member checked with the authors of the original case study and adjusted to represent consensus of understanding among all authors.

\section{Findings}

The eight schools were generally strong in all the categories analyzed, consistent with their selection as exemplar school models and confirming the fit of the categories used in this analysis. Ratings for each category within each school are presented in Table 5. The table shows there was variation in how the schools addressed each theme, yet the schools were largely consistent in their use of these curricular and instructional elements. The variations demonstrate design and contextual choices rather than issues of quality. 
Table 5.

Average prominence and utility ratings for coding themes

\begin{tabular}{|c|c|c|c|c|c|c|c|c|}
\hline Heading \& Theme & School A & School B & School C & School D & School E & School F & School G & School H \\
\hline \multicolumn{9}{|l|}{ Classroom Implementation } \\
\hline $\begin{array}{l}\text { School focuses on students' learning the content to } \\
\text { the level of mastery }\end{array}$ & 3 & 3 & 3 & 2 & 1 & 3 & 3 & 1 \\
\hline $\begin{array}{l}\text { School extensively uses non-traditional curricular } \\
\text { content sources }\end{array}$ & 3 & 3 & 2.5 & 3 & 3 & 3 & 1 & 2 \\
\hline \multicolumn{9}{|c|}{ Cross-cutting School Level Learning Opportunities } \\
\hline $\begin{array}{l}\text { Collaborative group projects are required in a } \\
\text { variety of formats \& foci }\end{array}$ & 2.5 & 3 & 3 & 3 & 3 & 2.5 & 2 & 3 \\
\hline $\begin{array}{l}\text { Students participate in summative or culminating } \\
\text { experiences }\end{array}$ & 1.5 & 3 & 3 & 3 & 3 & 2.5 & 0 & 3 \\
\hline $\begin{array}{l}\text { School frequently uses interdisciplinary courses } \\
\text { and/or projects }\end{array}$ & 2.5 & 2.5 & 3 & 3 & 3 & 3 & 3 & 3 \\
\hline \multicolumn{9}{|l|}{ School-wide Design } \\
\hline $\begin{array}{l}\text { Curriculum and schedule are designed to provide } \\
\text { academic rigor }\end{array}$ & 2 & 3 & 3 & 3 & 3 & 3 & 3 & 3 \\
\hline Nearly all students take high rigor courses & 3 & 3 & 3 & 3 & 2.5 & 3 & 1.5 & 2 \\
\hline Schools offer engineering / design thinking & 1 & 2.5 & 2.5 & 3 & 3 & 3 & 1 & 3 \\
\hline $\begin{array}{l}\text { Emphasis on real world connections \& 21st } \\
\text { century skill building }\end{array}$ & 3 & 2.5 & 3 & 3 & 3 & 2.5 & 3 & 2 \\
\hline Strong teacher collaboration & 2.5 & 3 & 3 & 3 & 3 & 2 & 3 & 3 \\
\hline \multicolumn{9}{|l|}{ Responsive Design } \\
\hline $\begin{array}{l}\text { Schools use data-driven decision making to } \\
\text { improve instruction }\end{array}$ & 3 & 3 & 2.5 & 3 & 2.5 & 2.5 & 2.5 & 2 \\
\hline $\begin{array}{l}\text { Schools are challenged with the entry level skills } \\
\text { of incoming 9th graders }\end{array}$ & 3 & 2.5 & 3 & 3 & 3 & 2 & 3 & 3 \\
\hline
\end{tabular}

Note: Participating schools requested anonymity on prominence and utility ratings

The remainder of this paper will explain how the categories within the four themes were enacted and how they varied across the schools. The four themes used to organize the discussion, from smaller to larger, are (a) classroom-related STEM opportunities, (b) cross-cutting school level STEM learning opportunities, (c) school-wide design for STEM learning and (d) systems and practices schools use to respond to needs in STEM curriculum and instruction. The relationship among the four headings will be explained in the discussion section of this paper.

\section{Classroom-related STEM opportunities}

Mastery learning. A significant feature across the schools was supporting mastery learning by providing multiple opportunities for students to complete learning tasks, as well as timely and meaningful feedback. Teachers offered differentiated learning strategies and used data systems for feedback on individual student learning to improve the supports they provided to keep students in heterogeneously leveled classes. Students who do not initially meet mastery standards were given the opportunity to try again and retake the assessments. This was not seen by students as failure, but as part of the learning process. A student at DLMHS stated,

This school is harder because we have harder classes but we have the ability to retake. Other schools don't have that option. This school is focused on mastery. This school is really about giving you chances, letting you have the ability to retake, and just get better at it instead of just saying you didn't do well on the first time so you're done. This school wants you to actually learn the concept.

Five of the eight ISHSs had school-wide data systems to monitor mastery learning. DSST perhaps had the most detailed data system, which entailed a list of objectives to be met over the course of a year. Once a teacher observed a student mastering that objective three times, they recorded this in the online system and the student moved on to other objectives. Other schools, such as Metro, USA, CHSAS, and DLMHS used electronic grading programs to record student mastery progress.

Non-traditional curricular content resources. As a group, these schools sought out non-traditional curricular content sources as a basis for classroom instruction and rarely used traditional textbooks. The sources of curriculum used in ISHSs included teacher generated projects, collaborations with higher education faculty, 
adaptations of Project Lead the Way curriculum, and internet-based media such as Khan Academy.

The schools expected their teachers to be designers of curricula, with minimum reliance on published textbooks. The schools felt this teacher-designed curriculum and instruction was more motivating and engaging for students and helped to keep curriculum and instruction innovative. At $\mathrm{HTH}$, teachers integrated topics across subject matter and co-taught these courses. Since the topics and teacher pairings changed from year to year, the teachers were proficient at designing original curriculum while still meeting state standards.

\section{Cross-cutting School Level STEM Learning Opportunities}

Collaborative group projects. Seven of the eight schools used collaborative group projects to provide authentic learning opportunities for students. The exception was DSST, which did not have a school-wide effort to promote projects. Rather, DSST teachers individually taught using projects in their classroom, especially in required engineering classes.

The formats of the school-wide collaborative group projects took a variety of forms. Manor and HTH adopted project-, problem-, and challenge-based learning as the format for all curriculum and instruction. One instance was a HTH unit titled "Sound Mind, Sound Body," which integrated naturalist writing and human body systems, and used weekly hikes to contextualize both physical training and exploration of the humanities. CHSAS also used collaborative group projects in students chosen agriculture pathways, integrating mathematics, science, history and language arts content in purposeful ways. Examples included exploring the chemistry behind horticulture, connecting mathematics and psychology principles to commodity prices, and applying human geography to dairy markets in the agricultural finance course. The principal, Bill Hooks, explained,

[Teachers] try to make these interdisciplinary connections. We all brought down our curriculum maps a few years ago and said...If you're studying the Great Depression in U.S. history and you're reading Grapes of Wrath in English let's do those simultaneously. In our agriculture class, let's cover the impact on soil erosion during the Dust Bowl years.

Summative and culminating projects. Another school-level learning opportunity found across all of these exemplar schools were projects that engage students in authentic learning experiences that serve as summative or culminating experiences such as gateway projects, capstone experiences, and other assignments that were designed for cohesion across and reflection on learning experiences. An example of summative projects was seen at $\mathrm{HTH}$, where students compiled and presented their best work in personal digital portfolios at the end of their HTH career. The digital portfolios provided a comprehensive look at each student's work and learning, and included a personal statement, resume, and work samples. Students updated their digital portfolios each semester, documenting and reflecting on their learning over time.

Some schools used community connections to help students apply their STEM knowledge to real world contexts. At Manor, students were required to complete a Capstone Project Senior Year in order to graduate. Past capstone efforts included community service projects such as producing a $5 \mathrm{~K}$ run to benefit a college scholarship, designing and selling bracelets for a college scholarship for undocumented children, and creating a documentary to create an awareness of local public finance malfeasance. All students had professional mentors outside of school, whom the students identified and engaged in their projects. The mentors helped students understand the professional skills and knowledge they needed to accomplish their goal.

Interdisciplinary courses or projects. Six of the eight case study schools had the requirement of interdisciplinary courses and/or projects. The use of interdisciplinary courses and projects at the schools brought students together across grade levels, across courses, or even at the whole school level. Such programs ranged in frequency - Metro assigned a whole school, cross-grade project once each year, while Manor used projects across subjects throughout the school year. Some interdisciplinary projects combined two classes, while others combined a larger range of subjects. DLMHS assigned a project across classes in Medical Ethics, English, Physics and Government, in which students chose a physical disability and students in this medical 
focused high school designed an innovation to improve the lives of those living with such disabilities.

Manor and HTH both used a full-time project-based learning (PBL) instructional approach. At Manor, most courses offered for those in 11th and 12th grades were cross-disciplinary including Physics/Algebra II, Scientific Research and Design/Statistics, and Environmental Science/Pre-Calculus. These courses were taught by pairs of teachers in block periods. At $\mathrm{HTH}$, most courses fully integrated two subject areas. An integrated humanities and biology course at HTH was structured around the theme of human experience in the natural world, covering both human physiological systems as well as naturalist writing. Mathematics, however, was the only field not included in this course pairing system. HTH school leaders felt strongly that the mathematics curriculum was diminished by forcing it to be integrated with other subjects, and believed that students were better prepared for college mathematics by not integrating it with other subjects.

Interdisciplinary projects were also offered at Metro, which used semester-long design challenge projects, in which students from all four grade levels were grouped to explore topics such as sustainable farming and living in their local region. Metro also had juniors participate in semester-long "learning center" courses, which combined high school courses with courses at Ohio State University (OSU) to explore Human Body Systems or Energy, Environment and Economics.

Of a shorter duration, USA offered week-long interdisciplinary units designed to make learning relevant to students. At this school, the 10th grade students explored housing conditions of migrant workers with a science component (energy efficiency), a mathematics component (cost), and a communication component (Spanish class). Another week-long project had 10th grade students take the role of video game developers and design a video game for a teenage brain. Students wrote computer code for their game, explored relevant science and chemistry concepts, and wrote a business proposal for their game. The motivations and payoffs for using projects lasting a week, a semester or a year included reinforcing the curriculum by circling back to ideas already taught, providing real world applications for STEM content knowledge and skills, as well as building interdisciplinary connections.

\section{School-wide Design for STEM opportunities}

Rigorous curriculum and schedule. The eight schools in this study used several strategies in class scheduling and class requirements to ensure all students at their school were held to high expectations. One strategy used was to design all students' graduation requirements more rigorous than state graduation requirements. Often these additional requirements involved courses in advanced science, mathematics, technology or engineering. All of the schools required that students complete up to at least the level of precalculus for their mathematics credits. To meet these high expectations, schools used innovative course scheduling. Aimee Kennedy, Chief Academic Officer at Metro explained, "in a regular school, 9th graders take Algebra I, but [many of those students] can never get through pre-calculus in that system." Metro addresses this issue by placing 9th and 10th grade students in intensive, one-semester-long courses that cover what normally would take two semesters in most high schools. Students enroll in four of these intensive academic classes each semester, in addition to a six-week January term between the two semesters. This way, students efficiently cover required courses and earn more than the average number of high school credits each year. Similarly, Manor used a trimester system, which allowed students to accrue 1.5 times the number of credits in a single year as schools on a two semester system.

Certainly some students in more typical, comprehensive high schools take college preparatory offerings and other courses beyond the basic graduation requirements. The significance of the schools in this study is that these requirements are held for all students, no matter what skill level or preparation they bring as incoming 9th graders. The requirements are met through supports provided by the schools. At Manor, where there were a number of students scoring below expectations on state mathematics assessments, the school offered an additional basic mathematics course in its trimester system so that students could still be ready for Calculus by senior year. 
The one school that did not clearly fit this theme was Boston USA, which was forced by its district to "absorb" another school which was underperforming two years before the site visit. At the time of the visit, USA strongly encouraged all students to take at least one AP class before graduation, yet the school staff acknowledged that "we need more rigor and we are constantly working on that. It is not a subject we take lightly."

Engineering/design thinking. Five of the eight schools held a strong focus on engineering or design thinking and required at least one engineering course. At Wayne, all incoming 9th graders took honors Engineering the Future and honors Applications of Science, both courses designed by school staff. After the freshman courses, Wayne engineering courses were offered in partnership with engineering instructors from the local community college. Beyond classes, the engineering design process was also incorporated into most of the courses taught at Wayne. The Wayne Principal explained, "No one should just be satisfied doing something one time and turning it in. It's always tinkering with it and making it better. That's kind of what we want to teach our kids." Engineering and design thinking were also prominent at other schools. HTH had a strong design thinking focus, Metro's engineering teachers were trained and certified by Project Lead The Way (PLTW), and Manor offered a two course PLTW-based engineering sequence as well as electives in digital electronics and a robust Robotics Club.

Engineering as a school theme or course of study was less prominent in the remaining schools, but these schools still provided some inquiry experiences for students. Even DLMHS, a medical focused high school that offered no engineering courses, did offer design thinking experiences. In each of their four years, students completed long term interdisciplinary projects. CHSAS had an agriculture focus, but the hands-on aspect of the curriculum provided a real world practicality. A chemistry teacher explained, "in a cookbook-lab, the logic is laid out. With inquiry like this ... they can go back and review decisions or errors they may have made for next time. If you're doing research in a lab, you don't just do something to figure it out. You talk about it with your team and have a plan in place. You still make mistakes and that's ok."

Science was a major focus at USA, and while they explored offering engineering, they ran out of resources and struggled with staff capacity. The one place in which engineering appeared was in the context of science, where one teacher reported including the topics of bioengineering and molecular engineering in the AP Biology course.

Emphasis on real-world connections. Across the eight schools, a consistent theme was supporting students to face challenges outside of school. Toward this end, these schools helped students build work and metacognitive skills including collaboration, problem solving, information and media literacy, and selfdirected learning. The PBL schools (Manor and HTH) as well as the schools with significant project-based learning opportunities (DLMHS and CHSAS) achieved this through shared language used by teachers and staff throughout the school. DLMHS held students to school wide learning outcomes known as VITAL Signs, and requiring every student to be Verbal, Intellectual, Technological, Academic, and a Leader. Seniors at DLMHS were required to present and defend a portfolio of their work that demonstrated their use of VITAL Signs over their four years of study. Students and staff at Metro also had quick access to their Metro Habits of Mind (Effective Communicators, Inquiring Learners, Active and Responsible Decision Makers, Effective Collaborators, Critical Thinkers, and Engaged Learners) through posters and conversations throughout the school. Each year, students participated in schoolwide Design Challenges that were designed to foster "interdisciplinary learning as well as the creativity, critical thinking, and collaboration skills that make up" these habits.

Secondly, these schools also had strong connections to partners outside of schools and opportunities to apply concepts students were learning in authentic settings. DLMHS relied upon an advisory committee of representatives from local hospitals and health care settings; HTH frequently invited scientists, engineers, and other STEM professionals to attend panels, give students feedback, or provide pre-project advice on design; USA used external partnerships including Urban Ecology Institute at Boston University, Bunker Hill Community College, and the Cloud Foundation to build and expand their curriculum. At DSST, the staff took a deliberate approach to balance the academic rigor of classes with application of STEM principles to the real world. 
Strong teacher collaboration. At five of the eight schools, teachers and school leaders described strong schoolwide teacher collaboration, supported by school culture and time regularly scheduled for this work. Teachers worked to help coordinate class learning goals, provide peer review for lessons, and conduct shared student assessment.

Other schools in the sample which did not have substantial co-teaching or shared projects still used structures within weekly or daily schedules for professional learning communities, common planning time, curriculum meetings, group reflection sessions, and group lesson tuning. At Wayne and Manor, group lesson tuning was done on a weekly basis, in which a teacher or group of teachers shared a lesson design and accompanying student work. Other teachers, within and outside of their discipline, provided feedback and discussion with the goal of improving student learning for that particular lesson. At DSST, where there were no cross-curricular projects or co-teaching, the staff had a strongly collaborative value and practices, in which teachers of similar courses worked toward the same standards and end-of-term exams, and teachers of sequential courses collaborated to ensure students were prepared for each subsequent course they took. Supporting these coordination goals were schedules which allowed for daily common planning time, twice monthly departmental meetings, and having regular time during the school day to plan together (Spillane, 2017).

\section{Responsive Design}

Data-driven decision-making. The ISHSs demonstrated the use of data-driven decision making, systems of coordinated teaching and management practices using student data to make informed decisions about instruction planning and management (Hamilton et al., 2009), at both the classroom level and at the school level. At the school level, data-driven decision making used student achievement data to inform choices made about curriculum and instruction. A prominent example of this was at DSST, which created highly flexible and adaptive instruction using student achievement data. Each fall and spring, staff used standardized assessments at the 9th, 10th and 11th grade levels to place students into performance bands so that instructors could target their similar needs. In addition, DSST teachers took two days after each trimester to analyze student performance data and design subsequent instruction that focused directly on particular student needs identified from the gap analysis. Metro used Measures of Academic Progress (MAP) testing to help place each incoming 9th grade student in the appropriate mathematics class. Metro had a Data Coordinator staff member who supervised MAP testing, student placement, as well as tracking student performance in courses. Metro also worked closely with OSU, their higher education partner, to track students' credits, grade point averages, and any successes or challenges faced in the college courses taken while at Metro, both to support students and to inform the level of rigor of their curriculum.

At the classroom level, many of the schools focused curriculum adaptation on the subject of mathematics. At DLMHS, USA, and Manor, the Principals noted that many students enter the school as 9th graders unprepared to achieve in mathematics. The schools used student assessment data to adapt courses to support struggling students. At USA, students were placed in appropriate mathematics courses based on the results of a pre-test, regardless of student status as 9th graders. At DLMHS, mathematics teachers used a repeated quiz system to assess student mastery of standards. While DLMHS did not use a school wide data system to drive instruction, the Principal explained that teachers adapted the curriculum to suit the students' needs:

"Our math teachers actually took the Algebra curriculum and they broke it into concepts. As the teachers presented the concepts, they regularly tested the students. A student will be tested on every concept five times, so that if they haven't got it in the beginning and they start getting it, they can pass. Teachers rotated the concepts, so that "On a concept quiz there would be four or five concepts. For example, one quiz will cover concepts one through four. The next week will cover concepts two through five, followed by another quiz on concepts three through six, and then four through seven. So, they're tested on those repeatedly and then they can go back in, get more help, and take them over." 
HTH used data to decide as a school to teach a stand-alone mathematics class because they noted that advanced mathematics was difficult to teach as integrated into the problem-based learning units. The Chief Academic Officer (CAO) felt strongly that the mathematics curriculum was diminished by forcing it to be integrated with other subjects. Though it was integrated at one time, the school made the decision to separate it based on past poor student performance in mathematics, parent feedback, and student feedback.

Challenges with incoming ninth graders. In light of the high expectations the schools had for students, all eight schools faced challenges with the entry level skills of incoming 9th graders, particularly in the subject of mathematics. Several schools addressed this challenge by using a flexible schedule. At DSST, students took two and sometimes three periods of mathematics or reading per day to develop their skills so that they were prepared for pre-calculus during their senior year. These students took extra core classes rather than taking electives. Metro and CHSAS focused on rigorous background courses in grades 9 and 10 before students took integrated application courses. USA scheduled two teachers to co-teach all course classes in 9th and 10th grade, effectively reducing the teacher-student ratio. As the USA principal stated, "I think having those classes at those two grade levels being co-taught makes a big difference in how our kids succeed, as it gives students the additional support necessary to successfully navigate through the transition from middle school."

Some of the schools addressed student support within the class structures. At DLMHS, teachers deconstructed the Algebra class, one of the most difficult for new students to pass, in to concepts and created smaller iterative cycles of assessment to pinpoint student needs which students could retake when they sought help in their deficient areas. HTH recruited the 11th grade students to mentor the 9th grade students. During 9th grade projects, teams are joined by 11th graders who give them advice as they progress through projects.

Some of the schools chose to overcome the challenge of student with lower entry level skills by preparing middle school students to function well in their high school settings. At the time of the visit, WSE was building a middle school in the same space as the high school and had instituted a 6th grade, with 7th and 8th grade being added each subsequent year. HTH also had an elaborate school system that included multiple elementary, middle, and high schools in addition to a graduate school for teacher training.

\section{Discussion}

\section{Common practices across the ISHSS}

While each school was unique in design, culture and resources, there were similar approaches to the shared goal of STEM success for students. The schools adopted a mission of preparing students for STEM college majors and careers requires rigorous preparation. The school schedule was purposefully designed for rigorous STEM learning (Cotabish, Dailey, Robinson \& Hughes, 2013; Lamberg \& Trzynadlowski, 2015) and success in these high-level courses was expected for all students attending the school, regardless of background, thus providing opportunity structures for all students. Through the use of non-conventional resources materials and partnerships, teachers created supports for students to succeed in STEM courses. This is consistent with the findings of Certo, Cauley, and Chafin, (2003), Eleftheria, Soririou, and Doran (2016), and Fang (2013) who found that challenging students with rigorous material through authentic, interdisciplinary learning experiences helped students value what they were doing in school and motivated them to master higher levels of content and skills. The ISHSs shared the goal of graduating students prepared for demanding studies of mathematics beyond levels to which typical comprehensive high schools aspire, even if additional coursework was required. In doing so, the schools created opportunities for students to pursue STEM as a career if they decided that route.

The schools in this study used innovative instructional approaches. By encouraging and supporting teachers to use student-centered techniques, collaboration in the classroom, frequent cycles of feedback to students, and summative or cumulative projects across all high school grades, these schools provided learning 
environments where students were expected to play an active role in their learning. Morrison, Roth-McDuffie, and French (2015) also found that student collaboration and social interaction were key in effective teaching and learning in a STEM school. These types of instructional practices are not often used, as less than half of American high school students report working in groups, and little class time is devoted to student-centered discussions (Cocoran, \& Silander, 2009). ISHSs provided opportunity structures by helping students to manage their own learning and to become self-aware of their strategies for achievement.

The ISHSs in this study were purposefully designed to emphasize real-world connections and 21st Century skills such as communication, collaboration, problem-solving and self-directed learning through integrated subject matter. Teachers and administrators at these schools understood that academic capital is no longer built with how much content a person knows, but how to locate, evaluate, and apply knowledge to solve problems and design new ideas. ISHSs capitalized on the authentic nature of learning by creating inclass and across-class integration of subject matter (Denson, Austin, Hailey, \& Householder, 2015). Authentic problem or project based scenarios easily became part of the curriculum because of the premium on integrated subject matter. The curriculum design and instructional implementation reflected this way of learning through authentic, contextualized and interdisciplinary lessons that encouraged collaboration rather than isolation. Certo, Cauley, and Chafin, (2003) found that students were more engaged in an instructional program that included authentic experiences, challenging activities, and worked to build student interest in learning and interpersonal relationships with adults and peers. The schools in this study corroborate this finding.

Teachers used these same 21st Century skills to develop lessons. Teachers worked together on the design of lessons, and sometimes on the implementation of lessons, regardless of disciplinary background, which further demonstrated the value they placed on interdisciplinary, collaborative problem solving (Breiner et al., 2012; Johnson, 2013). Bidwell and Yasumoto (1999) found a similar phenomenon in their study on faculty organizational control, finding three themes: (a) faculty social organization provided structural and normative capacity for control of instruction, (b) local cultures of practice emerged, and (c) focus in each subject depended on the strength of the norms of practice in each field.

Finally, the schools were small and nimble, using flexible scheduling strategies and multiple sources of data to hone in on student and school needs (Ford, 2017). The ISHSs had systematic ways of collecting data on student progress using a variety of sources to build a full picture of the student and could provide informed, individualized learning for their students. Similarly, Cooper, Ponder, Merritt, and Matthews (2005) found that data-directed dialogue and collaborative instruction was a factor in high performance on state assessments for high schools. The data collection and analysis techniques at the eight schools in this study were key in supporting students who had not yet met standards for the rigorous learning expectations.

Emerging from these similarities, a model of inclusive STEM high schools was constructed as portrayed in Figure 1. Students experienced STEM learning opportunities through both classroom activities and strategies (including mastery learning, and relying on non-traditional content sources) and through school level opportunities and features (including group projects and summative projects, as well as interdisciplinary courses or projects). These learning opportunities both shaped and were shaped by school-wide STEM features and approaches (including course scheduling, scheduling students into courses, ensuring engineering or design thinking are accessible, providing real-world connections and 21st Century skill building, and supporting teachers through collaboration). Linking the classroom and school levels together through mutual influence were responsive design systems. 


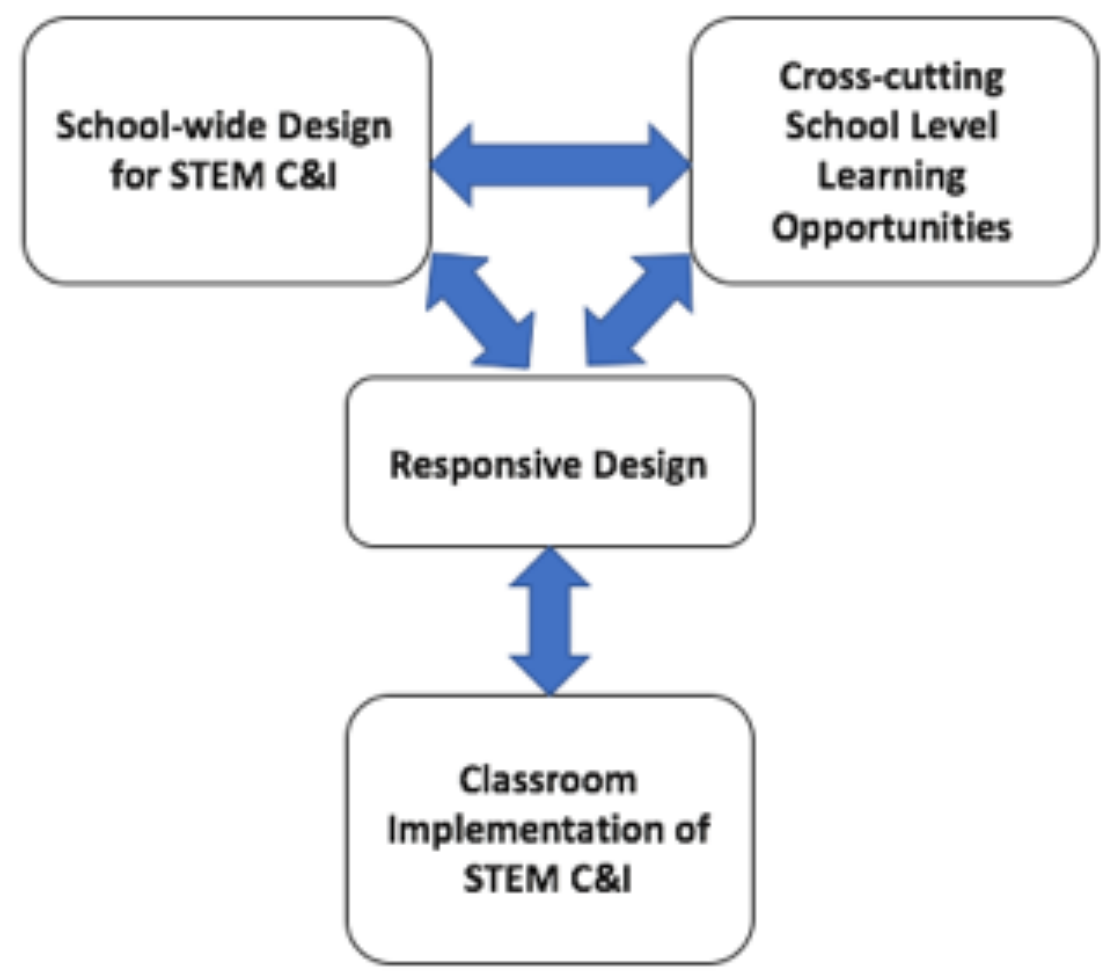

Figure 1. Model of Inclusive STEM High School Curriculum and Instruction

\section{Unique contextual characteristics}

All of the schools in this study had devised ways to create opportunities for their students through classroom implementation, cross-cutting school-level learning, school-wide design, and did so in ways that were responsive to the needs and interests of the students and the school community. However, the context in which the school operated and the resources available to the schools differentiated the ways that the schools accomplished these aims. The eight schools in the study had three different categories of what they valued in terms of curriculum and instruction: PBL-focus (Manor and HTH), college credit focus (Wayne, Metro, and DSST), or career focus (CHSAS, DLMHS, and USA). Some schools, such as Manor and HTH, wanted their students to have extensive problem-solving skills and focused their efforts toward student production. Whereas other schools, such as Wayne, Metro and DSST, focused their efforts toward early college credits for their students. The last group of schools, CHSAS, DLMHS and USA, were focused on providing opportunities for students to experience skill and knowledge building through the context of career development (van Breukelen, D., Smeets, M., \& de Vries, M., 2015). To a certain extent, these choices directed the partnerships the schools built (Watters \& Diezmann, 2013). For example, HTH leveraged extensive community support and strong partnerships with industry professionals and businesses locally. Therefore, authentic PBL learning coupled with collaboration with partners and assessment of student work by professionals was a natural fit to create more STEM opportunities. Wayne and Metro were designed to include local institutions of higher education, thus partnering to offer early college credit for students was their way of developing STEM opportunities. CHSAS designed curriculum for students to gain basic academic knowledge for the first two years of high school and then transition to an entirely integrated pathway that focused on career development. The schools were thoughtful about how they built STEM curriculum and instruction given their context and their local resources, devising their own ways of offering intensive and rigorous STEM in preparation for students' future success. 


\section{Implications}

National organizations including PCAST (2010a; 2010b) and the National Research Council (2011) have called for more research all types of STEM schools: selective, inclusive, and career technical. The results of this cross-case analysis contribute to much needed literature on the curriculum and instruction in STEM schools with strong outcomes, thus contributing to a baseline for further study and delivering insights to policy makers regarding designing and supporting STEM education (Breiner et al., 2012; Johnson, 2013). School staff wishing to increase their STEM offerings or build a STEM-focused school can look to the variety of ways that the exemplar schools created opportunities for their students based on their own contexts. One of the aims of the study was to document ISHSs from a wide variety of school environments in order to provide relatable school environments for other schools wishing to increase their STEM curriculum and instruction focus. School staff can use the four categories of STEM-focused activities from this study to organize their efforts in classroom implementation, cross-class curriculum design, school-wide design, and responsive design in their own schools. Although each of the exemplar schools in this study invented their own way of addressing STEM curriculum design and instructional implementation, there were common factors to the design and implementation of the curriculum and instruction which can guide other schools.

Beyond viewing this rich set of practices and design features as separate elements for adoption and adaptation, the findings of this analysis also demonstrate that these eight exemplar settings for inclusive and effective STEM education bring the identified components together into a school model (Figure 1). The curricular and instructional elements identified in this study were, nearly always, significant aspects of each of the eight school designs. Certainly a single teacher or a single department can incorporate some of the features examined in this analysis. Yet the school level and cross cutting features were also important aspects of the curriculum and instruction of these exemplar schools (Eleftheria, Sotiriou, \& Doran, 2016) and likely were crucial to the high rates of student success (see Author \& Colleagues, 2017 for more detailed explanation of student outcomes for the eight ISHSs). The combination of these features at both the classroom and schoolwide level, then, provides a synergistic result, noteworthy for those wanting to better understand and emulate the success of highly effective inclusive STEM high schools.

The most significant limitation of this study is it contains only eight schools within its analysis. It also focuses on a specific type of high school, rather than being able to speak about the larger field of secondary education. Yet the detail and rigor of the eight cases analyzed, and their established success providing secondary STEM education for students underrepresented in STEM fields offers a unique set of insights into effective STEM curricular and instructional strategies.

\section{References}

Atkinson, R. D., Hugo, J., Lundgren, D., Shapiro, M. J. \& Thomas, J. (2007). Addressing the STEM challenge by expanding specialty math and science high schools. Washington, DC: National High School Center. Retrieved from http://www.ncsssmst.org

Colleague \& Author. (2008). Bill and Melinda Gates Report.

Peters-Burton, E. E., Behrend, T., Lynch, S. J. \& Means, B. (2014). Inclusive STEM high school design: Ten critical components. Theory into Practice, 53, 1-8.

Author and Colleagues. (2018). Journal of Research in Science Teaching.

Banilower, E. R., Smith, P. S., Weiss, I. R., Malzahn, K. A., Campbell, K. M., \& Weis, A. M. (2013). Report of the 2012 National Survey of Science and Mathematics Education. Chapel Hill, NC: Horizon Research, Inc.

Bidwell, C. E. \& Yasumoto, J. Y. (1999). The collegial focus: Teaching fields, collegial relationships, and instructional practice in American high schools. Sociology of Education, 72(4), 234 - 256. 
Breiner, J., Harkness, M., Johnson, C. C., \& Koehler, C. (2012). What is STEM? A discussion about conceptions of STEM in education and partnerships. School Science and Mathematics, 112(1), 3-11.

Carroll, M. (2015). Stretch, dream, and do: A 21st Century design thinking \& STEM journey. Journal of Research in STEM Education, 1(1), 59-70.

Certo, J. L., Cauley, K. M., \& Chafin, C. (2003). Students' perspectives on their high school experience. Adolescence, 38(152), $705-725$.

Chung, C. J., Cartwright, C., \& Cole, M. (2014). Assessing the impact of an autonomous robotics competition for STEM education. Journal of STEM Education, 15(2), 24-34.

Corcoran, T. \& Silander, M. (2009). Instruction in high schools: The evidence and the challenge. The Future of Children, 19(1), 157-183.

Cooper, J. E., Ponder, G., Merritt, S., \& Matthews, C. (2005). High-performing high schools: Patterns of success. National Association of Secondary School Principals, 89(645), 2-24.

Cotabish, A., Dailey, D., Robinson, A., \& Hughes, G. (2013). The effects of a STEM intervention on elementary students' science knowledge and skills. School Science and Mathematics, 113(5), 215-226.

Denson, C. D., Austin, C., Hailey, C., \& Householder, D. (2015). Benefits of informal learning environments: A focused examination of STEM-based program environments. Journal of STEM Education, 16(1), 11-19.

Eleftheria, T., Sotiriou, S., \& Doran, R. (2016). The "Big Ideas of Science" for the school classroom: Promoting interdisciplinary activities and the interconnection of the science subjects taught in primary and secondary education. Journal of Research in STEM Education, 2(2), 72-89.

Elmore, R. (1996). Getting to scale with good educational practice. Harvard Educational Review, 66(1), 1-27.

Eisenhart, M., Weis, L., Allen, C. D., Cippolone, K., Stich, A., \& Dominguez, R. (2015). High school opportunities for STEM: Comparing inclusive STEM-focused and comprehensive high schools in two US cities. Journal of Research in Science Teaching, 52(6), 763-789.

Fang, N. (2013). Increasing high school students' interest in STEM education through collaborative brainstorming with yo-yos. Journal of STEM Education, 14(4), 8-14.

Ford, M. (2017). Approaches to school leadership in inclusive STEM high schools: A cross-case analysis (Doctoral dissertation). Retrieved from PQDT Open (AAT 10259145).

Grubbs, M. E., \& Deck, A. (2015). The water turbine: An integrative STEM education context. Technology \& Engineering Teacher, 75(2), 26-30.

Hamilton, L., Halverson, R., Jackson, S. S., Mandinach, E., Supovitz, J. A., Wayman, J. C., Pickens, C., Martin, E., \& Steele, J. L. (2009). Using Student Achievement Data to Support Instructional Decision Making. United States Department of Education, Retrieved from http://repository.upenn.edu/gse_pubs/279

Hiller, S. E., \& Kitsantas, A. (2014). The effect of a horseshoe crab citizen science program on middle school student science performance and STEM career motivation. School Science and Mathematics, 114(6), 302-311.

Johnson, C. C. (2013). Conceptualizing integrated STEM education. School Science and Mathematics, 113(8), 367-377.

Lamb, R., Akmal, T., \& Petrie, K. (2015). Development of a cognition-priming model describing learning in a STEM classroom. Journal of Research in Science Teaching, 52(3), 410-437.

Lamberg, T. \& Trzynadlowski, N. (2015). How STEM Academy teachers conceptualize and implement STEM education. Journal of Research in STEM Education, 1(1), 45-58.

Lent, R.W., Brown, S.D., \& Hackett, G. (1994). Toward a unifying social cognitive theory of career and academic interest, choice, and performance. Journal of Vocational Behavior, 45(1), 79-122. 
Lynch, S. J., Spillane, N., House, A., Peters-Burton, E. E., Behrend, T., Ross, K. M., \& Han, E. (2017). A policyrelevant instrumental case study of an inclusive STEM-focused high school: Manor New Tech High. International Journal of Education in Mathematics, Science and Technology, 5(1), 1-20.

Lynch, S. J., Peters-Burton, E. E., Behrend, T., House, A., Ford, M., Spillane, N., Matray, S., Han, E., \& Means, B. (2018). Understanding inclusive STEM high schools as opportunity structures for underrepresented students: Critical components. Journal of Research in Science Teaching. DOI 10.1002/tea.2143

Mehta, J. \& Cohen, D. (2017). Why reform sometimes succeeds: Understanding the conditions that produce reforms that last. American Educational Research Journal, 54(4), 607-643.

Mohr-Schroeder, M. J., Jackson, C., Miller, M., Walcott, B., Little, D. L., Speler, L., Schroeder, D. C. (2014). Developing middle school students' interests in STEM via summer learning experiences: See Blue STEM Camp. School Science and Mathematics, 114(6), 291-301.

Morrison, J., Roth-McDuffie, A., \& French, B. (2015). Identifying key components of teaching and learning in a STEM school. School Science and Mathematics, 115(5), 244-255.

Naizer, G. (2014). Narrowing the gender gap: Enduring changes in middle school students' attitude towards math, science, and technology. Journal of STEM Education, 15(3), 29-34.

National Research Council. (2004). Engaging schools: Fostering high school students' motivation to learn. Committee on Increasing High School Students' Engagement and Motivation to Learn. Washington, DC: National Academies Press.

National Research Council. (2005). How students learn: History, mathematics, and science in the classroom. Committee on How People Learn, A Targeted Report for Teachers. M.S. Donovan and J.D. Bransford (eds.). Washington, DC: National Academies Press.

National Research Council. (2010). Preparing teachers: Building evidence for sound policy. Committee on the Study of Teacher Preparation Programs in the United States. Washington, DC: National Academies Press.

National Research Council. (2011). Successful K-12 STEM education: Identifying effective approaches in science, technology, engineering, and mathematics. Committee on Highly Successful Science Programs for K-12 Science Education. Board on Science Education and Board on Testing and Assessment, Division of Behavioral and Social Sciences and Education. Washington, D.C.: The National Academies Press.

National Research Council. (2012). A framework for K-12 science education: Practices, crosscutting concepts, and core ideas. Committee on a Conceptual Framework for New K-12 Science Education Standards. Board on Science Education, Division of Behavioral and Social Sciences and Education. Washington, DC: The National Academies Press.

NGSS Lead States (NGSS). (2013). Next Generation Science Standards: For States, By States. Washington, DC: The National Academies Press.

Oyana, T. J., Garcia, S., Hawthorne, T., Haegele, A., Morgan, J., Young, N. (2015). Nurturing diversity in STEM fields through geography: The past, the present, and the future. Journal of STEM Education, 16(2), 2129.

President's Council of Advisors on Science and Technology (PCAST). (2010a). Prepare and inspire: K-12 education in science, technology, engineering, and mathematics (STEM) for America's future. Washington, DC: Author.

President's Council of Advisors on Science and Technology (PCAST). (2010b). Engage to excel: Producing one million additional college graduates with degrees in science, technology, engineering, and mathematics. Washington, DC: Author.

Rahm, J., \& Moore, J. C. (2015). A case study of long-term engagement and identity-in-practice: Insights into the STEM pathways of four underrepresented youths. Journal of Research in Science Teaching, 3(5) 768801. 
Rennie, L.,Venville,G., \& Wallace, J. (2012). Integrating science, technology, engineering, and mathematics: Issues, reflections, and ways forward. New York: Routledge.

Reynolds, D., Yazdani, N. Mazur, T. (2013). STEM high school teaching enhancement through collaborative engineering research on extreme winds. Journal of STEM Education, 14(1), 12-19.

Roehrig, G. H., Moore, T. J., Wang, H. H., \& Park, M. S. (2012). Is adding the E enough? Investigating the impact of K-12 engineering standards on the implementation of STEM integration. School Science and Mathematics, 112(1), 31-44.

Roberts, K. (1968). The entry into employment: An approach towards a general theory. Sociological Review, 16, 165-184.

Sahin, A. (2013). STEM clubs and science fair competitions: Effects on post-secondary matriculation. Journal of STEM Education, 14(1), 5-11.

Scott, C. E. (2009). A comparative case study of characteristics of science, technology, engineering, and mathematics (STEM) focused high schools. Retrieved from Proquest (AAT 3365600).

Spillane, N. K. (2017). Teacher characteristics and school-based professional development in inclusive stem-focused high schools: A cross-case analysis. Retrieved from Proquest (AAT 3687663).

Stake, R. E. (2006). Multiple case study analysis. New York, NY: The Guilford Press.

Subotnik, R.F., Tai, R. H., Rickoff, R., Almarode, J. (2010). Specialized public high schools for science, mathematics, technology and the STEM pipeline: What do we know now and what will we know in five years? Roeper Review, 32, 7-16.

van Breukelen, D., Smeets, M., \& de Vries, M. (2015). Explicit teaching and scafolding to enhance concept learning by design challenges. Journal of Research in STEM Education, 1(2), 87-105.

Watters, J. J., \& Diezmann, C. M. (2013). Models of community partnerships for fostering student interest and engagement in STEM. Journal of STEM Education, 14(2), 47-55.

Yin, R. K. (2003). Case study research: Design and methods (3rd ed.). Thousand Oaks, CA: Sage Publications, Inc. 